\title{
Broussonetia papyrifera (paper mulberry): its growth, yield and potential as a fallow crop in slash-and-burn upland rice system of northern Laos
}

\author{
K. Saito $\cdot$ B. Linquist $\cdot$ B. Keobualapha $\cdot$ \\ T. Shiraiwa $\cdot$ T. Horie
}

Received: 6 September 2007 / Accepted: 4 January 2009/Published online: 21 January 2009

(C) The Author(s) 2009. This article is published with open access at Springerlink.com

\begin{abstract}
In northern Laos, shortened fallows in the slash-and-burn upland rice system are not sustainable either from a production or economic standpoint. This paper evaluates the potential for using the indigenous fast-growing tree, Broussonetia papyrifera L. Vent. (paper mulberry) as an economic fallow crop. The objectives of this study are to assess the inner bark yield of paper mulberry, and to evaluate rice productivity following paper mulberry cultivation. In addition, allometric models for estimating the inner bark yield of paper mulberry are developed. Inner bark yield of paper mulberry stands ranging in age from 9 to 48 months ranged from 10 to $208 \mathrm{~g} \mathrm{~m}^{-2}$, and increased with age. The models using diameter at breast height and stem height, or diameter at breast height only as independent variables explained well
\end{abstract}

K. Saito · T. Shiraiwa - T. Horie

Graduate School of Agriculture, Kyoto University,

Kyoto 606-6502, Japan

K. Saito $(\bowtie)$

Africa Rice Center (WARDA), 01 B.P. 2031, Cotonou,

Benin

e-mail: k.saito@cgiar.org

B. Linquist

Department of Plant Sciences, University of California,

Davis, CA 95616, USA

B. Keobualapha

Provincial Agriculture and Forestry Office, Luang

Prabang, Lao People's Democratic Republic the variation in inner bark yield. When paper mulberry was completely removed during the rice growing season, rice yields in these areas were similar to those following weedy bush fallow. When paper mulberry was allowed to grow, rice yields were negatively correlated to paper mulberry stem density. When paper mulberry lateral branches were pruned back, rice yields could be maintained if the paper mulberry stem

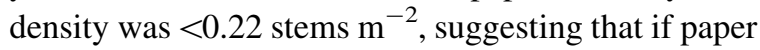
mulberry is managed properly, rice yields can be maintained at current levels. The paper mulberryupland rice rotation system improves the productivity of a traditional slash-and-burn system through harvesting paper mulberry inner bark; however the longterm sustainability of such a system remains unclear and warrants further investigation.

Keywords Allometric model .

Broussonetia papyrifera · Fallow .

Inner bark - Laos · Paper mulberry ·

Slash-and-burn $\cdot$ Upland rice

\section{Introduction}

Slash-and-burn upland rice remains the dominant land-use system in the mountainous region of northern Laos. Farmers in this region have depended on perennial species to suppress weeds and rejuvenate soil fertility during the fallow period as well as to 
provide daily necessities such as food and firewood (Roder 2001). Rapid population growth and government policies aimed at protecting forests no longer permit traditional slash-and-burn management with long fallows and this has resulted in increased cropping intensity; increased weed and pest pressure; and consequently lowered rice yields (Roder 2001; Saito et al. 2006). These shortened fallows using traditional management practices are not sustainable and the development of stable alternatives is required.

This paper evaluates the potential of the indigenous Broussonetia papyrifera L. Vent. (paper mulberry) as an improved fallow crop. Paper mulberry is a fastgrowing, non-leguminous tree of the Moraceae family that is distributed in East and Southeast Asia (Fahrney et al. 1997). In northern Laos, the inner bark has long been harvested from natural stands for local processing into a coarse-textured parchment. It is a multipurpose tree with the inner bark used to make paper, the stems for firewood, and the leaves for animal feed. The recent development of domestic processing industries and improved market channels have encouraged farmers to grow paper mulberry as a cash crop (Hamman 2001).

Paper mulberry is commonly found growing on moist alluvial soils, such as valley floors and stream banks, but it is also a common species in slash-andburn fields during the fallow period. Paper mulberry is easily established in upland fields using root suckers or root cuttings (Forsén et al. 2001; Linquist et al. 2005, 2006; LSFP 2001) so it can continue to grow after harvesting the rice. Paper mulberry can be harvested for its bark 1-2 years after initial establishment and annually thereafter until the next rice crop. The paper mulberry trees that have been onceharvested have a faster growth rate than newly planted ones since they have already established a root system. Paper mulberry is harvested primarily at the end (March-April) and beginning (September-October) of the dry season (Forsén et al. 2001). A paper mulberry tree may have one or several primary stems. After cutting suitable-sized stems and secondary branches, the inner and outer bark are stripped using a knife, and then the inner bark is separated from the outer bark. The inner bark is dried in the sun before selling (Fahrney et al. 1997). When the land is prepared for upland rice cropping, all fallow vegetation including paper mulberry is cut and burned. Following the burning, the established paper mulberry readily regenerates from roots and stems to continue the next cycle. While information on establishment methods and management for paper mulberry has been reported on elsewhere (Forsén et al. 2001; Linquist et al. 2005; LSFP 2001), the effect of paper mulberry cultivation on upland rice productivity is not known. Furthermore, there is little information on the productivity of paper mulberry in terms of bark yield and above-ground biomass in northern Laos. Recently, Tajima et al. (2001) developed an allometric model using one-year-old paper mulberry with stem densities of $0.12-0.5$ stems $\mathrm{m}^{-2}$ for estimating single stem inner bark yield in eight locations in Thailand. However, this model is only applicable for one-year-old stands at low density, since bark yield may be sensitive to age and stem density.

Therefore, the objectives of this study were (1) to develop an allometric model that could estimate the inner bark yield of paper mulberry in stands of differing age and stem density, and (2) to assess paper mulberry as a fallow crop and the management options for paper mulberry during the rice growing season to maintain rice yields and improve the productivity of an upland rice slash-and-burn system.

\section{Materials and methods}

\section{Description of study area}

All field studies were conducted in Pak $\mathrm{Ou}$ and Xiengngun districts $\left(\mathrm{N} 19^{\circ} 42^{\prime}-20^{\circ} 13^{\prime}, \mathrm{E} 102^{\circ} 08^{\prime}-20^{\prime}\right.$, about 320-350 masl), Luang Prabang province, Laos. This province has the highest proportion of upland rice cultivation in the country, with about $70 \%$ of the total rice area being used for upland rice. Average annual rainfall is $1,300 \mathrm{~mm}$ but is erratic and about $80 \%$ of rainfall occurs during the upland rice growing season (May-October). Monthly rainfall at the Northern Regional Agriculture and Forestry Research Center (NAFReC) in Xiengngun district has been reported in Saito et al. (2008).

Assessment of inner bark yield of paper mulberry

A field study was conducted in 24 established paper mulberry stands during March and April of 2003 and 2004. The age of these stands (time since establishment or regeneration) ranged from 9 to 48 months. A 
$25 \mathrm{~m}^{2}$ plot within each stand was selected and within this area stem height (from the soil surface to the top of the stem), stem diameter at breast height (diameter at $1.3 \mathrm{~m}$ above-ground level; DBH), and inner bark yield were measured for all stems of which DBH was greater than $15 \mathrm{~mm}$. Stem height was measured after cutting at $20 \mathrm{~cm}$ at ground level. A total of 423 individual stems were analyzed across all sites. Additionally, from each $25 \mathrm{~m}^{2}$ plot 3-5 randomly selected stems (of which DBH was $>15 \mathrm{~mm}$ ) were taken to determine the total above-ground biomass based on the dry weight of the inner and outer bark; leaves; stem; and secondary branches (diameter $<15 \mathrm{~mm}$, inner and outer bark were not removed). The stems and secondary branches were weighed fresh in the field and sub-samples (at least $0.2 \mathrm{~kg}$ ) were taken to determine moisture content.

Simple or multiple regression analyses were conducted to identify the relationships between bark yield $\left(\mathrm{g} \mathrm{m}^{-2}\right)$ and stem height $(\mathrm{cm})$, DBH $(\mathrm{cm})$, stem density (stems $\mathrm{m}^{-2}$ ), and age (month). Allometric models were developed from the natural log-transformed data of inner bark yield ( $\mathrm{g} \mathrm{stem}^{-1}$ or $\mathrm{g} \mathrm{m}^{-2}$ ), total or merchantable stem height $(\mathrm{cm})$, DBH $(\mathrm{cm})$, stem density (stems $\mathrm{m}^{-2}$ ), age (month) and some of their products $\left(\mathrm{DBH}^{2} \times\right.$ stem height). The adjusted coefficient of determination (adjusted $R^{2}$ ) and root mean square error (RMSE) were used to select the best-fit model.

\section{Upland rice productivity following paper} mulberry cultivation

Four field experiments were conducted to assess upland rice yield following paper mulberry cultivation. In 2002 and 2003 experiments were conducted on farmers' fields in Somusanuk and Pathung (villages in Pak Ou district), respectively. In 2004 and 2005 experiments were conducted on the same field at NAFReC. Prior to the experiments, paper mulberry had been growing for the previous 3 years in Somsanuck and 4 years in Pathung. At NAFReC, paper mulberry was established in a field in 2002; it was cut and harvested before planting rice in 2004 and 2005. At the initiation of each field experiment, the land was prepared according to traditional slash-and-burn practices; all fallow vegetation, including paper mulberry (except for the bark which was removed at NAFReC), was slashed and burned. There was no further land preparation and traditional rice cultivars were planted in all fields using a dibble stick, as is the traditional practice, Experiments in the farmers' fields (Somusanuk and Pathung) were managed by the farmers (i.e., their own rice cultivars; planting density was not uniform), while those at NAFReC were managed by researchers. In NAFReC, traditional rice cultivars (Vieng in 2004 and Laboun in 2005) were planted using a dibble stick with holes spaced at $0.25 \times 0.25 \mathrm{~m}$, and approximately ten seeds in each hole. Weeds were controlled as necessary.

Treatments were established in each field based on the density of paper mulberry. Plot size differed among and within the fields, ranging from 12 to $80 \mathrm{~m}^{2}$. In each field, 12 plots were identified at the beginning of the season with varying paper mulberry stem density from as low as 0.06 to more than 2.8 stems $\mathrm{m}^{-2}$ (Table 1). In four plots in the Somsanuck and Pathung fields and six plots in the 2004-NAFReC fields, some paper mulberry stems were removed in order to obtain a wider range of paper mulberry density. Additionally, in four plots in Somsanuck and Pathung, all paper mulberry was removed. In the 2005-NAFReC experiment, paper mulberry stem density was controlled at a stem density of $0.06-$ 0.42 stems $\mathrm{m}^{-2}$, and the paper mulberry lateral branches were pruned back three times during the rice growing season. This management practice is used by farmers to reduce competition between the rice and paper mulberry. Within each field, three to four areas were randomly selected with areas outside paper mulberry plots where no paper mulberry was growing. This area was the control area and is referred to as a bush fallow. At maturity, rice yields (reported at 14\% moisture) were determined from 8.0 to $71.25 \mathrm{~m}^{2}$, and the heights of three to ten randomly selected stems of paper mulberry within each plot were recorded. In each experiment, mean rice yields for the plots (1) following bush fallow (control), (2) where paper mulberry was removed (Somsanuck and Pathung fields only), and (3) where paper mulberry was allowed to grow with rice at different stem densities were analyzed to test whether rice yields following paper mulberry cultivation differ from those after bush fallow (Table 1). An unbalanced analysis of variance was conducted for this analysis, since the number of plots differed among treatments in each experiment (Table 1). Simple regression and correlation analyses were applied for identifying 
Table 1 Number of plots in each treatment for four experiments in Luang Prabang province, Laos

\begin{tabular}{llcc}
\hline & Bush fallow (control) & PM removed & $\begin{array}{l}\text { Paper mulberry with rice at } \\
\text { different densities (range of PM stem density; } \\
\text { stem m }\end{array}$ \\
\hline Somsanuck & 3 & 4 & $8(0.10-1.25)$ \\
Pathung & 4 & 4 & $8(0.17-2.79)$ \\
2004-NAFReC & 3 & 0 & $12(0.10-1.00)$ \\
2005-NAFReC & 3 & 0 & $10(0.06-0.42)^{\mathrm{c}}$ \\
\hline
\end{tabular}

${ }^{a}$ No paper mulberry existed during the previous fallow period

b Paper mulberry stems were removed during rice growing season

c In the 2005-NAFReC experiment where the paper mulberry was retained, its branches were pruned to reduce competition. Two plots could not be harvested, due to severe damage by brown spot and root aphids

relationships between rice yield, paper mulberry stem density and height at time of rice harvest.

Eight to ten soil samples $(0-15 \mathrm{~cm})$ were taken and pooled from each field. Soil samples were airdried and sieved before analysis. Soil $\mathrm{pH}$ was determined in a 1:1 ratio of soil:water; extractable $\mathrm{P}$ using the Bray 2 method (Nanjo 1997); total carbon and $\mathrm{N}$ using a trace mass spectrometer (Tracer MAT, Thermo Quest Co. Ltd., Tokyo); available $\mathrm{NH}_{4}-\mathrm{N}$ by the indophenol method (Hidaka 1997); and available $\mathrm{NO}_{3}-\mathrm{N}$ by the Griess-Ilosvay method after reduction to $\mathrm{NO}_{2}$ (Hidaka 1997).

\section{Results}

Assessment of inner bark yield of paper mulberry

The stem density of paper mulberry ranged from 0.24 to 2.24 stems $\mathrm{m}^{-2}$ in the 24 plots surveyed. Stem height and DBH on average ranged from 238 to $801 \mathrm{~cm}$ and from 1.8 to $6.9 \mathrm{~cm}$, respectively. Inner bark yield and total above-ground biomass ranged from 10 to $209 \mathrm{~g} \mathrm{~m}^{-2}$ and 140 to $3,611 \mathrm{~g} \mathrm{~m}^{-2}$, respectively. The inner bark yield was highly correlated with total above-ground biomass $(r=0.96$, $P<0.01)$. On average over the plots, the inner bark yield, outer bark and leaves, accounted for 6.2, 4.4, and $4.3 \%$ of the total above-ground biomass, respectively. The inner bark yield of paper mulberry increased linearly $(r=0.83, P<0.01)$ between 9 and 48 months (Fig. 1), although there was large variation in yields for trees of the same age. The variation may be due to combined effects of stem density, soil quality, water availability and manage-

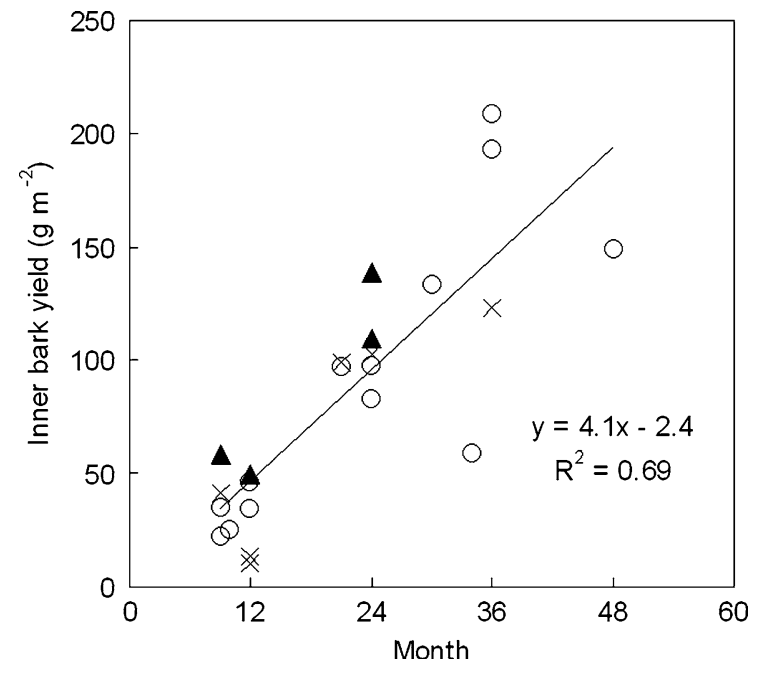

Fig. 1 Inner bark yield of paper mulberry in relation to age. The line shown is for data from all of the plots surveyed. " $x$ ", " $\bigcirc$ " and " $\boldsymbol{\Delta}$ ' show stem densities of $<0.5$ stems $\mathrm{m}^{-2}, 0.5$ or more but not exceeding 1.0 , and 1.0 or more stems $\mathrm{m}^{-2}$, respectively

ment (i.e., weeding, intercropping, etc.). There were significant linear relationships between stem height or DBH and inner bark yield across all of the data ( $r=0.91, \quad P<0.01$ for stem height; $r=0.63$, $P<0.01$ for DBH). The relationship between stem density and inner bark yield across all sites was not significant; however, for stands that were less than oneyear-old there was significant relationship between stem density and inner bark yield [inner bark yield $\left(\mathrm{g} \mathrm{m}^{-2}\right)=18.2+19.7 \times$ stem density $\left(\right.$ stems $\left.\mathrm{m}^{-2}\right)$; $r=0.70, P<0.05, n=10]$. This relationship was not significant for stands older than one-year-old (data not shown). 
For estimating inner bark yield per stem, eight regression models were evaluated using the natural $\log$-transformed data of inner bark yield $\left(\mathrm{g} \mathrm{stem}^{-2}\right)$, stem height $(\mathrm{cm}), \mathrm{DBH}(\mathrm{cm})$, age (month) and stem density ( stems $\mathrm{m}^{-2}$ ) (Table 2). All regression models are statistically significant. High adjusted $R^{2}(89-$ $90 \%)$ and small RMSE values (0.36-0.38) in regression models 1, 3, 6 and 8 (Table 2) signify that these models are good indicators of how the inner bark yield is related to the independent variables. The model developed by Tajima et al. (2001) with $\mathrm{DBH}^{2} \times$ height as independent variables also explained the variation in inner bark yield in our data without any biases $\left[\ln \left(\right.\right.$ inner bark yield stem $\left.^{-1}\right)=$ $-2.855+0.846 \times \ln \left(\mathrm{DBH}^{2} \times\right.$ stem height $) ; R^{2}=$ 0.90]. All of these models are applicable to paper mulberry stands differing in age and stem density across Thailand and northern Laos. However, since DBH is easy to measure accurately in the field, the model which only requires this measurement (regression model 1 in Table 2) is recommended for estimating inner bark yield per stem for practical purposes.

Upland rice productivity following paper mulberry cultivation

Rice yields following bush fallow were highest in Somsanuck $\left(236 \mathrm{~g} \mathrm{~m}^{-2}\right)$, where extractable $\mathrm{P}$ and total carbon contents in the soil were the highest, and lowest $\left(<100 \mathrm{~g} \mathrm{~m}^{-2}\right)$ in NAFReC (Tables 3,4$)$. The lower rice yields in $\mathrm{NAFReC}$ were associated with low extractable soil P; shorter fallows (one-year plus dry season in 2004 and dry season in 2005); and incidences of brown spot disease and root aphid (Tetraneura nigriabdominalis), which was observed in both years. These results are consistent with previous studies (Saito et al. 2006, 2007).

Paper mulberry stem density at rice maturity ranged

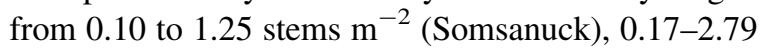
stems $\mathrm{m}^{-2}$ (Pathung), 0.10-1.00 stems $\mathrm{m}^{-2}$ (2004NAFReC) and 0.06-0.42 stems $\mathrm{m}^{-2}$ (2005-NAFReC), except for plots where paper mulberry was removed in Somsanuck and Pathung (Table 1). High variation in the paper mulberry height at rice maturity was observed in all fields except for Somsanuck. The height of paper mulberry at rice maturity ranged from 159 to $187 \mathrm{~cm}$ (Somsanuck), 205-324 cm (Pathung), 180-342 cm (2004-NAFReC) and 246-393 cm (2005NAFReC). Rice yields following paper mulberry cultivation ranged from 91 to $203 \mathrm{~g} \mathrm{~m}^{-2}$ in Somsanuck, $18-65 \mathrm{~g} \mathrm{~m}^{-2}$ in Pathung, 8-91 $\mathrm{g} \mathrm{m}^{-2}$ in 2004NAFReC and 63-139 $\mathrm{g} \mathrm{m}^{-2}$ in 2005-NAFReC, except for the plots where paper mulberry was removed in Somsanuck and Pathung.

In both Somsanuck and Pathung, rice yields following bush fallow were similar to those following paper mulberry cultivation where the paper mulberry

Table 2 Regression equations for estimating inner bark yield per stem of paper mulberry using different models and combinations of independent variables

\begin{tabular}{|c|c|c|c|c|c|c|}
\hline No & Regression model & $a$ & $b$ & $c$ & $R^{2 \mathrm{a}}$ & $\mathrm{RMSE}^{\mathrm{b}}$ \\
\hline 1 & $\mathrm{Ln}(\mathrm{DW})=a+b \times \ln \left(\mathrm{DBH}^{2}\right)$ & 1.52 & 1.22 & & 0.89 & 0.38 \\
\hline 2 & $\operatorname{Ln}(\mathrm{DW})=a+b \times \ln (\mathrm{h})$ & -12.10 & 2.64 & & 0.68 & 0.65 \\
\hline 3 & $\mathrm{Ln}(\mathrm{DW})=a+b \times \ln \left(\mathrm{DBH}^{2} \times \mathrm{h}\right)$ & -3.38 & 0.91 & & 0.90 & 0.37 \\
\hline 4 & $\mathrm{Ln}(\mathrm{DW})=a+b \times \ln (\mathrm{age})$ & 0.82 & 1.15 & & 0.27 & 0.99 \\
\hline 5 & $\operatorname{Ln}(\mathrm{DW})=a+b \times \ln (\mathrm{d})$ & 3.91 & -0.92 & & 0.17 & 1.06 \\
\hline 6 & $\mathrm{Ln}(\mathrm{DW})=a+b \times \ln \left(\mathrm{DBH}^{2}\right)+c \times \ln ($ age $)$ & 1.35 & $1.20(0.93)^{\mathrm{c}}$ & $0.08(0.03)$ & 0.89 & 0.38 \\
\hline 7 & $\mathrm{Ln}(\mathrm{DW})=a+b \times \ln \left(\mathrm{DBH}^{2}\right)+c \times \ln (\mathrm{d})$ & 1.54 & $1.20(0.93)$ & $-0.09(-0.04)$ & 0.89 & 0.39 \\
\hline 8 & $\mathrm{Ln}(\mathrm{DW})=a+b \times \ln \left(\mathrm{DBH}^{2} \times \mathrm{h}\right)+c \times \ln (\mathrm{d})$ & -3.20 & $0.88(0.92)$ & $-0.16(-0.07)$ & 0.90 & 0.36 \\
\hline
\end{tabular}

All regression equations are statistically significant $(P<0.01)$, based on 423 stems in Luang Prabang province, Laos $D W$ dry weight of inner bark $\left(\mathrm{g} \mathrm{stem}^{-1}\right)$

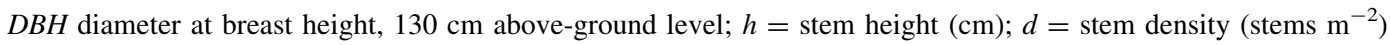

a The coefficient of determination

b Root mean square error

c Standardized partial regression coefficients 
Table 3 Rice yield and stem height of paper mulberry at rice harvest in four experiments in Luang Prabang province, Laos

\begin{tabular}{|c|c|c|c|c|c|c|c|}
\hline & \multicolumn{4}{|c|}{ Grain yield $\left(\mathrm{g} \mathrm{m}^{-2}\right)$} & \multirow{2}{*}{$\begin{array}{l}\text { Relative rice yield } \\
(\% ; b / a \times 100)\end{array}$} & \multirow{2}{*}{$\begin{array}{l}\text { PM stem density } \\
\left(\text { stems } \mathrm{m}^{-2}\right)^{\mathrm{c}}\end{array}$} & \multirow{2}{*}{$\begin{array}{l}\text { PM height at rice } \\
\text { harvest }(\mathrm{cm})^{\mathrm{c}}\end{array}$} \\
\hline & $\begin{array}{l}\text { Bush } \\
\text { fallow }(a)^{\mathrm{a}}\end{array}$ & $\begin{array}{l}\mathrm{PM} \\
\text { removed }^{\mathrm{b}}\end{array}$ & $\begin{array}{l}\text { PM with } \\
\text { rice }(b)^{\mathrm{c}}\end{array}$ & $\mathrm{PR}>\mathrm{F}$ & & & \\
\hline Somsanuck & $236 p^{d}$ & $250 p$ & $159 q$ & $P<0.01$ & 67 & 0.51 & 172 \\
\hline Pathung & $104 p^{d}$ & $109 \mathrm{p}$ & $38 \mathrm{q}$ & $P<0.01$ & 37 & 1.06 & 264 \\
\hline 2004-NAFReC & $69 p$ & - & $43 p$ & $P=0.11$ & 63 & 0.48 & 247 \\
\hline 2005-NAFReC & $93 p$ & - & $100 \mathrm{p}$ & $P=0.68$ & 107 & 0.19 & 336 \\
\hline
\end{tabular}

was removed (Table 1). When paper mulberry was allowed to grow with rice during the growing season, it competed strongly with the rice (Table 3). In all instances where paper mulberry was left to grow, rice yields were lower than for the bush fallow (control) or where all of the paper mulberry was removed except for 2005-NAFReC. The reduction in rice yields was related to paper mulberry stem density as rice yields declined with increasing stem density in all experiments where paper mulberry was allowed to grow (Table 5; Fig. 2). In two of the experiments, rice yield was negatively related to stem height of paper mulberry at rice maturity; however, the height was also correlated with the stem density (Table 5).

In the 2005-NAFReC experiment, where the paper mulberry was managed by pruning the lateral branches, the paper mulberry was taller than all the other experiments by the end of the rice growing season and rice yields were similar to that following a bush fallow (Table 3). Regression analysis showed that in this experiment, at stem densities of $<0.22$

Table 4 Soil properties of three experimental fields in Luang Prabang province, Laos

\begin{tabular}{lccc}
\hline & Somsanuck & Pathung & NAFReC \\
\hline $\mathrm{pH}$ & 5.8 & 5.6 & 5.8 \\
Total C $(\mathrm{g} / \mathrm{kg})$ & 27 & 20 & 21 \\
Total N (g/kg) & 2.4 & 2.0 & 2.8 \\
Extractable P (mg/kg) & 20 & 10 & 4 \\
Available N (mg/kg) & 31 & 18 & 30 \\
\hline
\end{tabular}

Soil sample was collected in 2002 stems $\mathrm{m}^{-2}$, rice yields were equal to or higher than the bush control but at densities higher than 0.22 stems $\mathrm{m}^{-2}$ rice yields were lower (Fig. 2).

\section{Discussion}

Harvesting paper mulberry bark from a paper mulberry-upland rice rotation system increases the overall productivity of these systems as long as the market price remains good (the price $\mathrm{kg}^{-1}$ for paper mulberry inner bark was about twice as high as that for rice in 2005). Based on the data used to develop our models for paper mulberry bark, farmers can harvest $0.48 \mathrm{t} \mathrm{ha}^{-1}$ year $^{-1}$ between upland rice crops (Fig. 1), which is equivalent to about $1 \mathrm{t} \mathrm{ha}^{-1}$ year $^{-1}$ rice grain, and represents more than half of averaged rice yield in this area $\left(1.7 \mathrm{t} \mathrm{ha}^{-1}\right.$ year $\left.^{-1}\right)$. Forsén et al. (2001) estimated that labor input (including weeding and harvesting) for producing $0.48 \mathrm{t}$ inner bark is 100 days, which is much less than that for upland rice cultivation (about 300 days $\mathrm{ha}^{-1}$; Roder 2001).

Key factors that need to be considered in ensuring sustainability and profitability of the system are first that the paper mulberry does not reduce rice yield, and second that the paper mulberry is at least as good if not better than a natural fallow. From a fallow improvement standpoint, our results suggest that paper mulberry does not improve rice productivity, but maintains it at current levels if the paper mulberry is managed properly during the rice growing season. These results are similar to others showing no 
Table 5 Correlation coefficients between rice yield, stem density and height of paper mulberry at four experiments in Luang Prabang province, Laos

\begin{tabular}{lrlll}
\hline & $n$ & \multicolumn{2}{l}{ Correlation coefficient } & \\
\cline { 2 - 4 } & & Stem density vs. rice yield & Stem height vs. rice yield & Stem density vs. stem height \\
\hline Somsanuck & 8 & $-0.91^{\mathrm{b}, \mathrm{c}}$ & $0.09 \mathrm{NS}$ & $0.19 \mathrm{NS}$ \\
Pathung & 8 & $-0.80^{\mathrm{a}, \mathrm{c}}$ & $-0.79^{\mathrm{a}}$ & $0.84^{\mathrm{b}}$ \\
NAFReC (2004) & 12 & $-0.76^{\mathrm{b}, \mathrm{c}}$ & $-0.57^{\mathrm{a}}$ & $0.58^{\mathrm{a}}$ \\
NAFReC (2005) & 10 & $-0.77^{\mathrm{b}, \mathrm{c}}$ & $-0.46 \mathrm{NS}$ & $-0.07 \mathrm{NS}$ \\
\hline
\end{tabular}

a Significant at 0.05 level

b Significant at 0.01 level

c Exponential or logarithmic regression were used for correlation analysis

Except for ${ }^{c}$ linear regression was used for correlation analysis

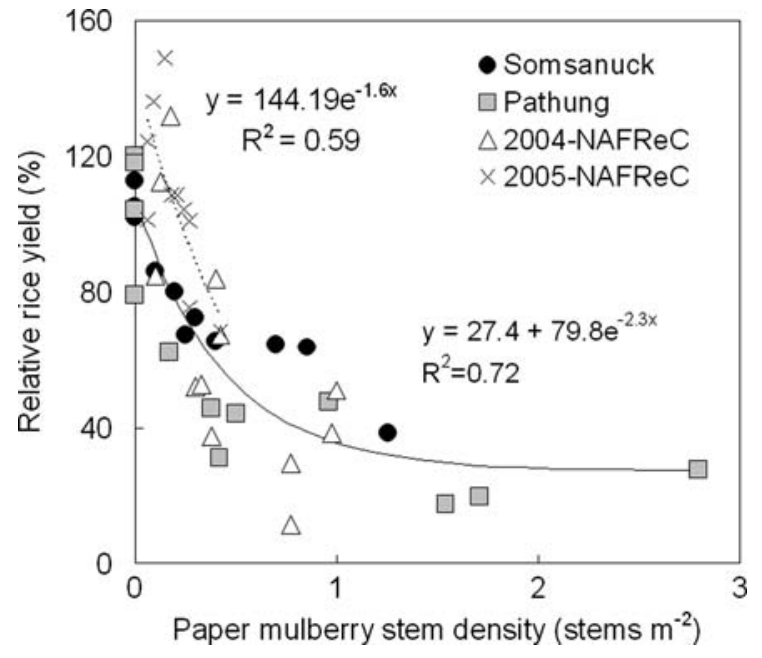

Fig. 2 Relative rice yield (relative to mean rice yield after bush fallow at each field) in relation to stem density of paper mulberry. (1) Data from three experiments (Somusanuck, Pathung and 2004-NAFReC) are combined for the regression (solid); (2) data from 2005-NAFReC, where the paper mulberry lateral branches were pruned three times during the rice growing season, are combined for the regression (dotted)

improvement over a bush fallow of legume tree fallows (Leucaena and pigeon pea) in northern Laos (Roder and Maniphone 1998; Roder et al. 1998; Saito et al. 2008). A review article on planted tree fallows in West Africa also reported that in $60 \%$ of cases, crop yields following tree-based fallows were not different from those of the control (Hauser et al. 2006). Good management during the rice growing season involves maintaining a low stem density at less than 0.22 stems $\mathrm{m}^{-2}$ and pruning branches (Fig. 2), confirming previous reports on farmer observations in relation to rice yields and paper mulberry cultivation (Fahrney et al. 1997; Forsén et al. 2001). However, the effect of this management may be that the paper mulberry bark yields are reduced in the first harvest after rice or there may be a longer period required until the first harvest (i.e., oneyear instead of 6 months).

In relation to the second factor, our data show that paper mulberry is as effective as a natural weedy fallow. However, as discussed earlier a two-year natural weedy fallow has not been shown to sustain yields in these upland rice systems. There was a trend for rice yield to decline with shortened paper mulberry cultivation period, consistent with the findings of others (Roder and Maniphone 1998; Roder et al. 1998; Saito et al. 2006, 2008) so longer fallows may be required to grow paper mulberry between rice crops. We did not address the long-term sustainability of this system in this research; however, if only the inner bark of the tree is removed from the system, a very small amount of nutrients will be removed. On the other hand, if bark, stems and leaves are all removed without any other nutrient inputs to the system, this system would not be considered sustainable from a nutrient management standpoint.

In summary, the paper mulberry-upland rice rotation system improves the economic productivity of a traditional slash-and-burn system through the use of paper mulberry as a cash crop. This system also maintains current rice yields in the short term but the long-term sustainability of such a system warrants further investigation. A simple model, using stem diameter at breast height, was developed that can predict the inner bark yield of paper mulberry across varying stand ages and stem densities. 
Acknowledgments The research was partly funded by the Swiss Agency for Development and Cooperation (SDC) and the "Global Environment Research Fund", The Ministry of the Environment, Government of Japan (Project S2-3b). The authors also would like to gratefully acknowledge the support and help they received from the staff of the Northern Regional Agriculture and Forestry Research Center and of the District Agricultural and Forestry Office in Pak Ou district.

Open Access This article is distributed under the terms of the Creative Commons Attribution Noncommercial License which permits any noncommercial use, distribution, and reproduction in any medium, provided the original author(s) and source are credited.

\section{References}

Fahrney KS, Boonnaphol O, Keoboulapha B et al (1997) Indigenous management of paper mulberry (Broussonetia papyrifera) in swidden rice fields and fallows in northern Laos. Paper presented at the regional workshop on indigenous strategies for intensification of shifting cultivation in Southeast Asia, Bogor, Indonesia, 23-27 June 1997

Forsén M, Larsson J, Samuelsson S (2001) Paper mulberry cultivation in the Luang Prabang province, Lao PDR, Minor Field Studies No 140

Hamman BR (2001) Final report. Study of the possibility of a small-scale industry relating to paper mulberry (Posa or Saa) submitted to JICA FORCAP. Vientiane, Lao PDR

Hauser S, Nolte C, Carsky R (2006) What role can planted fallows play in the humid and sub-humid zone of West and Central Africa? Nutr Cycl Agroecosyst 76:297-318. doi:10.1007/s10705-005-5630-4

Hidaka S (1997) Nitrogen. In: Committee for standard methods of soil analysis, Japanese society of soil science and plant nutrition (eds) Standard method of soil environment analyses (in Japanese), Hakuyusha, Tokyo

Linquist B, Saito K, Keoboualapha B, et al (2005) Developing upland rice based cropping systems. In: Bouahom B, Glendinning A, Nilsson S and Victor M (eds) Poverty reduction and shifting cultivation stabilization in the uplands of Lao PDR: technologies, approaches and methods for improving upland livelihoods. Proceedings of a workshop held in Luang Prabang, Lao PDR, 27-30 January 2004, National Agriculture and Forestry Research Institute, Vientiane, pp 299-313

Linquist B, Saito K, Keoboualapha B (2006) Improving upland rice-based cropping systems in Laos. In: Schiller JM, Chanphengxay MB, Linquist, Appa Rao S et al (eds) Rice in Laos. International Rice Research Institute, Philippines, pp 391-407

LSFP (LAO-SWEDISHFORESTRY PROGRAM) (2001) Research report, summary of on-station research at Thong Khang research station 1992-1999. National Agriculture and Forestry Research Center and LAO-SWEDISH FORESTRY PROGRAM, Vientiane

Nanjo M (1997) Available phosphate. In: committee for standard methods of soil analysis, Japanese society of soil science and plant nutrition (eds) Standard method of soil environment analyses, Hakuyusha, Tokyo (in Japanese)

Roder W (2001) Slash-and-burn rice systems in the hills of northern Laos PDR: description, challenges and opportunities. International Rice Research Institute, Los Banos

Roder W, Maniphone S (1998) Shrubby legumes for fallow improvement in northern Laos: establishment, fallow biomass, weeds, rice yield, and soil properties. Agrofor Syst 39:291-303. doi:10.1023/A:1005958729929

Roder W, Maniphone S, Keoboulapha B (1998) Pigeon pea for fallow improvement in slash-and-burn systems in the hills of Laos. Agrofor Syst 39:45-57. doi:10.1023/A:1005918 316157

Saito K, Linquist B, Keobualapha B et al (2006) Cropping intensity and rainfall effects on upland rice yields in northern Laos. Plant Soil 284:175-185. doi:10.1007/s11104006-0049-5

Saito K, Atlin GN, Linquist B et al (2007) Performance of traditional and improved upland rice cultivars under nonfertilized and fertilized conditions in northern Laos. Crop Sci 47:2473-2481. doi:10.2135/cropsci2006.12.0779

Saito K, Linquist B, Johnson DE et al (2008) Planted legume fallows reduce weeds and increase soil $\mathrm{N}$ and $\mathrm{P}$ contents but not upland rice yields. Agrofor Syst 74:63-72. doi: 10.1007/s10457-008-9149-y

Tajima M, Thaiutsa B, Puwangchit L et al (2001) Growth and allometry of 4 provenances of Thai paper mulberry (Broussonetia papyrifera) and 1 Japanese $\operatorname{Kozo}$ (B. kazinoki) grown in 8 regions in Thailand. Paper presented in international symposium on paper mulberry and handmade paper for rural development, Bangkok, 19-24 March 